\title{
From mechanisms to therapy: RNA processing's impact on human genetics
}

\author{
Luiz O. Penalva ${ }^{1} \cdot$ Jeremy R. Sanford $^{2}$
}

Published online: 2 September 2017

(C) Springer-Verlag GmbH Germany 2017

40 years ago, the laboratories of Philip Sharp and Richard Roberts reported the discovery of introns (Berget et al. 1977; Chow et al. 1977). Their seminal work revealed that proteincoding messenger RNAs (mRNA) are derived from much longer precursor transcripts (pre-mRNA) containing both exonic (coding) and intronic (non-coding) sequences. During the ensuing decades, the burgeoning field of pre-mRNA processing solved numerous molecular mechanisms underlying the catalysis of splicing, polyadenylation, RNA editing and translation.

Pre-mRNA processing has major impacts on gene expression. The human genome contains far fewer protein-coding genes than initially predicted. The final number, 19,215 , was less than a third of what had been expected and indicated that other modes of gene regulation, rather than just gene number, contribute to organism complexity (Jalali et al. 2016; Wright et al. 2016). The first transcriptomic maps built with data from the EST project illuminated an important source of information- alternative splicing and polyadenylation (Mironov et al. 1999). Three decades ago, these processes were seen as exceptions to the rule, but current estimates suggest that more than $95 \%$ of the human genes give rise to multiple transcripts (Frankish et al. 2015).

Jeremy R. Sanford

jsanfor2@ucsc.edu

Luiz O. Penalva

penalva@uthscsa.edu

1 Children's Cancer Research Institute, University of Texas Health Science Center at San Antonio, San Antonio, TX 78229, USA

2 Department of Molecular, Cellular and Developmental Biology, University of California Santa Cruz, Santa Cruz, CA 95060, USA
Protein-coding genes defy the one gene-one enzyme paradigm, in part, through the process of alternative pre-mRNA splicing. This mode of gene regulation is critical for generating protein isoforms with specific functions in development and homeostasis (Kalsotra and Cooper 2011). Alternative pre-mRNA processing not only expands the protein coding capacity of our genes, but also influences the regulation of downstream mRNA processing events such as translation, mRNA decay and transport in unexpected ways (Hachet and Ephrussi 2004; Sanford et al. 2004; Lareau et al. 2007; Ni et al. 2007; Wang et al. 2012; Sterne-Weiler et al. 2013; Floor and Doudna 2016; Taliaferro et al. 2016). These highly integrated steps in post-transcriptional gene are governed in part, through the interplay of trans-acting RNA binding proteins with a diverse array of $c i s$-regulatory elements scattered throughout the pre-mRNA (Fu and Ares 2014).

Human genes contain overlapping layers of information. For example, the genetic code is constrained by sequences that also regulate pre-mRNA splicing (Parmley et al. 2006; Warnecke and Hurst 2011). These overlapping codes complicate efforts to understand how genetic variation influences phenotype. Does a polymorphism within a codon affect transcript splicing or the protein structure and function? The impact of aberrant RNA processing on phenotype is now undeniable, as numerous human diseases, including cancer, arise from mutations in cis-acting RNA elements and trans-acting RNA binding proteins, as well as the creation of toxic repetitive RNA elements through nucleotide expansion (Faustino and Cooper 2003; Sterne-Weiler and Sanford 2014; Li et al. 2016).

Splicing alterations are a common topic among genetic disorders. In recent years, we have seen tremendous advance in respect to splicing and therapy. Currently, there are FDA approved modified anti-sense oligo-nucleotides that are capable to correct splicing alterations in SMN2, the key gene 
in Spinal Muscular Atrophy (Singh et al. 2017). This drug has been recently approved by the FDA and most patients are showing dramatic responses to treatment. Similar strategies could be used to treat a variety of Mendelian diseases.

The impact of RNA processing on cancer development is also well documented with long lists of genes implicated in all hallmarks of cancer, displaying wide-spread alterations in splicing and poly A site selection (Brooks et al. 2014; Wang et al. 2016). Genomic projects such as The Cancer Genome Atlas (TCGA) provided an additional and more powerful platform to identify global changes in the splicing profile of cancer cells and expression alterations of its regulators. These studies increased the catalogue of biomarkers, mapped novel tumor suppressors and oncogenes and established RNA processing as an import route towards malignancy (Sebestyen et al. 2015; Bjorklund et al. 2017).

This special issue on RNA processing is a tribute to this initial discovery that opened a new chapter of gene expression regulation. We assembled a collection of articles from expert labs, covering a variety of biomedical topics in data analysis, RNA processing mechanisms and aberrant RNA processing in inherited diseases and cancer. As editors of this special issue, it has been our goal to increase the awareness of the readership of Human Genetics of RNA processing as a mechanism that drives human phenotypic variation. We are grateful to the authors who have contributed such creative and scholarly work. Finally, we thank the senior editorial board and the production staff at Human Genetics for helping us to share this important corner of the RNA world with you.

\section{References}

Berget SM, Moore C, Sharp PA (1977) Spliced segments at the 5' terminus of adenovirus 2 late mRNA. Proc Natl Acad Sci USA 74:3171-3175

Bjorklund SS, Panda A, Kumar S, Seiler M, Robinson D, Gheeya J, Yao M, Alnaes GIG, Toppmeyer D, Riis M et al (2017) Widespread alternative exon usage in clinically distinct subtypes of Invasive Ductal Carcinoma. Sci Rep 7:5568

Brooks AN, Choi PS, de Waal L, Sharifnia T, Imielinski M, Saksena G, Pedamallu CS, Sivachenko A, Rosenberg M, Chmielecki J et al (2014) A pan-cancer analysis of transcriptome changes associated with somatic mutations in U2AF1 reveals commonly altered splicing events. PLoS ONE 9:e87361

Chow LT, Gelinas RE, Broker TR, Roberts RJ (1977) An amazing sequence arrangement at the $5^{\prime}$ ends of adenovirus 2 messenger RNA. Cell 12:1-8

Faustino NA, Cooper TA (2003) Pre-mRNA splicing and human disease. Genes Dev 17:419-437

Floor SN, Doudna JA (2016) Tunable protein synthesis by transcript isoforms in human cells. Elife 5

Frankish A, Uszczynska B, Ritchie GR, Gonzalez JM, Pervouchine D, Petryszak R, Mudge JM, Fonseca N, Brazma A, Guigo R et al
(2015) Comparison of GENCODE and RefSeq gene annotation and the impact of reference geneset on variant effect prediction. BMC Genom 16(Suppl 8):S2

Fu XD, Ares M Jr (2014) Context-dependent control of alternative splicing by RNA-binding proteins. Nat Rev Genet 15:689-701

Hachet O, Ephrussi A (2004) Splicing of oskar RNA in the nucleus is coupled to its cytoplasmic localization. Nature 428:959-963

Jalali S, Gandhi S, Scaria V (2016) Navigating the dynamic landscape of long noncoding RNA and protein-coding gene annotations in GENCODE. Hum Genom 10:35

Kalsotra A, Cooper TA (2011) Functional consequences of developmentally regulated alternative splicing. Nat Rev Genet $12: 715-729$

Lareau LF, Inada M, Green RE, Wengrod JC, Brenner SE (2007) Unproductive splicing of SR genes associated with highly conserved and ultraconserved DNA elements. Nature 446:926-929

Li YI, van de Geijn B, Raj A, Knowles DA, Petti AA, Golan D, Gilad Y, Pritchard JK (2016) RNA splicing is a primary link between genetic variation and disease. Science 352:600-604

Mironov AA, Fickett JW, Gelfand MS (1999) Frequent alternative splicing of human genes. Genome Res 9:1288-1293

Ni JZ, Grate L, Donohue JP, Preston C, Nobida N, O'Brien G, Shiue L, Clark TA, Blume JE, Ares M Jr (2007) Ultraconserved elements are associated with homeostatic control of splicing regulators by alternative splicing and nonsense-mediated decay. Genes Dev 21:708-718

Parmley JL, Chamary JV, Hurst LD (2006) Evidence for purifying selection against synonymous mutations in mammalian exonic splicing enhancers. Mol Biol Evol 23:301-309

Sanford JR, Gray NK, Beckmann K, Caceres JF (2004) A novel role for shuttling SR proteins in mRNA translation. Genes Dev 18:755-768

Sebestyen E, Zawisza M, Eyras E (2015) Detection of recurrent alternative splicing switches in tumor samples reveals novel signatures of cancer. Nucleic Acids Res 43:1345-1356

Singh NN, Howell MD, Androphy EJ, Singh RN (2017) How the discovery of ISS-N1 led to the first medical therapy for spinal muscular atrophy. Gene Ther. doi:10.1038/gt.2017.34

Sterne-Weiler T, Sanford JR (2014) Exon identity crisis: disease-causing mutations that disrupt the splicing code. Genome Biol 15:201

Sterne-Weiler T, Martinez-Nunez RT, Howard JM, Cvitovik I, Katzman S, Tariq MA, Pourmand N, Sanford JR (2013) Frac-seq reveals isoform-specific recruitment to polyribosomes. Genome Res 23:1615-1623

Taliaferro JM, Vidaki M, Oliveira R, Olson S, Zhan L, Saxena T, Wang ET, Graveley BR, Gertler FB, Swanson MS et al (2016) Distal alternative last exons localize mRNAs to neural projections. Mol Cell 61:821-833

Wang ET, Cody NA, Jog S, Biancolella M, Wang TT, Treacy DJ, Luo S, Schroth GP, Housman DE, Reddy S et al (2012) Transcriptomewide regulation of pre-mRNA splicing and mRNA localization by muscleblind proteins. Cell 150:710-724

Wang L, Brooks AN, Fan J, Wan Y, Gambe R, Li S, Hergert S, Yin S, Freeman SS, Levin JZ et al (2016) Transcriptomic characterization of SF3B1 mutation reveals its pleiotropic effects in chronic lymphocytic leukemia. Cancer Cell 30:750-763

Warnecke T, Hurst LD (2011) Error prevention and mitigation as forces in the evolution of genes and genomes. Nat Rev Genet 12:875-881

Wright JC, Mudge J, Weisser H, Barzine MP, Gonzalez JM, Brazma A, Choudhary JS, Harrow J (2016) Improving GENCODE reference gene annotation using a high-stringency proteogenomics workflow. Nat Commun 7:11778 